\title{
Agentes locales en la construcción de la imagen turística del Pueblo MÁGICO DE IZAMAL, ¿̇RODUCTORES O REPRODUCTORES?
}

\section{Local Agents in the Construction of the Tourist Image of the Magical TOWN OF IZAMAL: ProducERs OR RePRODUCERs?}

\author{
Francisco J. Fernández Repetto* \\ Mariana Guevara Rosado**
}

DOI: http://dx.doi.org/10.29043/liminar.v19i2.848

\begin{abstract}
Resumen: En la construcción de la imagen turística de un destino intervienen numerosos agentes (públicos y privados) a distintos niveles (local, nacional, global); estos agentes producen políticas, discursos y prácticas que procuran articularse sin contradicción ni conflicto para que la imagen turística sea homogénea y los mensajes que se transmitan mantengan uniformidad. En este artículo se analiza cómo los guías turísticos locales, situados en las posiciones de menor influencia en la producción de la imagen turística, entienden e interpretan su papel para apuntalar o contradecir la imagen turística de Izamal.
\end{abstract}

Palabras clave: turismo, agentes turísticos, promoción turística local.

Abstract: We find that in the construction of a tourist image of a destination, numerous agents (public and private) at different levels (local, national, global) intervene. These agents develop policies, discourses, and practices that they endeavor to coordinate without contradiction or conflict, so that the resulting tourist image is standardized and the messages transmitted are, therefore, uniform. In this article we analyze how local tour guides, i.e., those with minimal influence in developing a tourist image, understand and interpret their role either in support of or contradicting the tourist image of Izamal.

Key words: tourism, tourist agents, local tourist promotion.

\footnotetext{
* Francisco J. Fernández Repetto. Doctor en Antropología por la Universidad de Florida, Estados Unidos. Profesor-investigador en la Facultad de Ciencias Antropológicas de la Universidad Autónoma de Yucatán, México. Temas de especialización: antropología visual, antropología del turismo, identidad y rituales. Correo electrónico: frepettorama@gmail.com. ORCID: https:/orcid.org/0000-0003-4759-1410

** Mariana Guevara Rosado. Licenciada en Antropología Social por la Universidad Autónoma de Yucatán, México. Estudiante de maestría en
}

el Centro de Investigación y Docencia Económicas, México. Temas de especialización: antropología del turismo, mercantilización cultural. Correo electrónico: mguevara0391@gmail.com. ORCID: https:/orcid. org/0000-0002-4691-6116

Enviado a dictamen: 8 de mayo de 2020

Aceptación: 10 de agosto de 2020 


\section{Introducción}

L a década de 1920 marcó el inicio del interés institucional por parte del Estado nacional hacia el desarrollo turístico de México (Bellota, 2017). En un principio, México fue reconocido como un destino de sol y playa (mayormente por turistas extranjeros provenientes de Estados Unidos y Canadá); sin embargo, la fundación del Instituto Nacional de Antropología e Historia en 1939 no solamente tuvo efecto en relación con la conservación, investigación, protección y difusión del patrimonio mexicano, sino que estas mismas acciones representaron un primer esfuerzo hacia la diversificación turística del país. Con ello, se pretendía conectar "el cuidado del patrimonio arqueológico, antropológico, histórico y paleontológico con la industria sin chimeneas" (Bellota, 2017:4). El turismo cultural y étnico en el país siguió desarrollándose en décadas posteriores; durante el sexenio del presidente Carlos Salinas de Gortari se instauró el Proyecto de Pueblos Indígenas, Ecología y Producción para el Desarrollo Sustentable. De igual forma, en los años noventa del siglo pasado se impulsó la promoción de los atributos culturales de las diversas regiones del país y se crearon los programas Ciudades Coloniales, Mundo Maya y La Ruta de los Dioses, los cuales son considerados como antecedentes directos del programa Pueblos Mágicos.

Pueblos Mágicos es un programa de política turística de la Secretaría de Turismo Federal (Sectur) que fue creado en el año 2001 con el objetivo de que los visitantes de los grandes centros turísticos conocieran también los poblados cercanos. Busca actuar directamente sobre las localidades para crear una marca distintiva del turismo en México y, al mismo tiempo, pretende hacer del turismo un agente de desarrollo que contribuya a "elevar los niveles de bienestar, mantener y acrecentar el empleo, fomentar y hacer rentable la inversión" (Sectur, 2014). El objetivo general del programa es el siguiente:

Impulsar la competitividad de las localidades con la denominación Pueblos Mágicos para que su patrimonio turístico singular y auténtico, se transforme en una amplia gama de productos turísticos, en sus distintas formas y modalidades, capaces de atraer y fidelizar flujos de visitantes orientadas por las tendencias globales de viaje y con ello coadyuvar al desarrollo local sustentable e incluyente (Sectur, 2019:6).

Sus objetivos específicos señalan que el programa busca convertir el turismo en una herramienta de desarrollo sustentable, estimular la inversión, impulsar la creación y fomento de cadenas productivas, utilizar el turismo como una herramienta de consolidación y reconciliación social, impulsar la consolidación de destinos turísticos y empoderar los saberes del empresariado privado y social del turismo (Sectur, 2019:7). Así, una localidad recibe el nombramiento de Pueblo Mágico debido a que "a través del tiempo ha conservado su valor y herencia histórica cultural y la manifiesta en diversas expresiones a través de su patrimonio tangible e intangible irremplazable" (Sectur, 2019:8).

En los últimos años, los estudios sobre los pueblos mágicos de México han cobrado relevancia; tres ejemplos de este interés se manifiestan en las compilaciones realizadas por Hernández Mar (2015), por López Leviet al. (2015), y por López Levi y Valverde Valverde (2016), además de numerosos artículos publicados en Topofilia. Revista de Arquitectura, Urbanismo y Ciencias Sociales, ${ }^{1}$ la cual, por lo menos desde 2012, ha publicado artículos reflexivos sobre distintas aristas del Programa Pueblos Mágicos (PPM) y sus repercusiones en las localidades donde se ha implementado. No haremos un detallado recuento de cada uno de los temas abordados en ellos, baste señalar que tocan aspectos relacionados con el territorio, la gobernanza, la participación ciudadana, las políticas públicas, el patrimonio y la imagen turística, entre otros. Para el caso de Izamal, encontramos únicamente dos capítulos de Estrella Pozo (2015) y Pérez Castro, Dzul Nah y Collí Tun (2019) que abordan algunos aspectos de la imagen turística de Izamal y la producción artesanal en el marco de los pueblos mágicos.

La implementación del programa en México y su trayectoria desde 2001 han avanzado con paso firme con la incorporación continua de nuevos pueblos mágicos hasta alcanzar la cifra de 121. Sin embargo, la actual 
administración federal (2018-2024) no destinó fondos para el programa; aunque la sección PPM de la página web de la Sectur no está habilitada, la denominación "pueblo mágico" sigue presente en los artículos que presenta la propia secretaría. A pesar de ello se organizó, como una "evolución" de la Feria Nacional de Pueblos Mágicos, el Primer Tianguis de Pueblos Mágicos, que se realizó en Pachuca, Hidalgo, del 24 al 27 de octubre de 2019. En el evento de presentación del Tianguis, el secretario de Turismo, Miguel Torruco Marqués, señaló que "el próximo año se iniciará una cruzada de 'barrido y pintado’ de los 121 Pueblos Mágicos de México, con la participación de los estados, municipios y la federación" (Notimex, 2019). ${ }^{2}$

Izamal recibió la denominación de Pueblo Mágico en el año 2002, cuando ya existían otras tres localidades con el nombramiento, lo cual no impide que las autoridades gubernamentales y demás agentes turísticos del lugar nombren en el discurso turístico a Izamal como el "Primer Pueblo Mágico de México". 3

Son varios los agentes que intervienen en la composición de la imagen turística, entre ellos, los líderes de opinión, las empresas turísticas, agencias de viajes y periodistas, así como los gobiernos en sus tres niveles. Gran parte de la literatura sobre imagen se centra, como se verá más adelante, tanto en la manera como se construye la imagen turística, como en el impacto que esta tiene en los turistas. No obstante, poco énfasis se hace en quienes se encargan de materializarla en discursos y prácticas en el ámbito local. Es por ello que en este artículo nos ocupamos de los agentes locales (los guías turísticos) que intervienen, de manera marginal, quizás, pero no por ello menos importante, en la forma de interpretary transmitir la imagen turística de Izamal en el entorno local.

Así, aunque no se pueda medir el impacto que los discursos y prácticas de estos agentes locales tienen sobre los turistas que los contratan, sí ofrece una idea bastante clara de cómo estos, y quizás la población local, han desarrollado ideas propias que continuamente negocian en relación con la imagen turística de la ciudad de Izamal. De ahí nuestras preguntas: ihasta qué punto los guías turísticos locales producen o reproducen la imagen turística de Izamal? ¿Con qué recursos cuentan para hacerlo? ¿Cómo legitiman su discurso? ¿Qué idea de patrimonio y autenticidad producen o reproducen? En su caso, iqué alternativas proponen? ${ }^{4}$

Para aproximarnos a una respuesta, hemos dividido el artículo en cuatro partes. En la primera de ellas hacemos una revisión crítica del concepto "imagen turística" y sus relaciones con la mirada turística y la autenticidad; en la segunda parte abordamos los componentes de la imagen turística de Izamal después de presentar algunas características de la localidad. En la tercera parte, presentamos, contrastamos y analizamos los discursos y prácticas de los agentes locales en relación con la imagen turística promovida. Para terminar, hacemos un recuento de los hallazgos y revaloramos la necesidad de acercarnos de manera más puntual a los agentes locales como estrategia de comprensión de la imagen turística.

\section{Contexto y producción de la imagen turística}

Conviene situar la imagen turística y sus coetáneos, los imaginarios turísticos y la mirada turística, en un marco más amplio; por ello iniciamos con una aproximación al turismo cultural, que fue descrito ya en uno de los trabajos pioneros de la antropología del turismo.

El turismo cultural incluye lo "pintoresco", el "color local", los vestigios de un estilo de vida que desaparece y que yace en la memoria con sus casas de viejos estilos, tejidos caseros, carretas o arados tirados por caballos o bueyes, herramientas hechas a mano más que elaboradas por máquinas. Las actividades en el destino incluyen comida en posadas rústicas, presentaciones folclóricas, festivales de vino, o rodeos, que rememoran el viejo oeste (Smith, 1989:4-5, cursivas y comillas en el original, traducción propia)

Hoy día el turismo cultural se expresa, siguiendo a Du Cros y McKercher (2012), en la conjugación de cuatro elementos: el turismo, el empleo del patrimonio cultural (cultural heritage), el consumo de experiencias y productos, y el turista (2012:6). En este sentido, el turismo cultural es fundamentalmente consumidor del patrimonio 
o de la herencia cultural. Cabe sin embargo distinguir un tipo de turismo llamado patrimonial, entendido "como el turismo que está vinculado con los emplazamientos patrimoniales" (Calonge, 2011); de manera más específica se entiende como "viajar para experimentar los lugares, artefactos y actividades que auténticamente representan las historias y gente del pasado y del presente. Incluye la visita a recursos culturales históricos y naturales" (Gibson, 2015, traducción propia).

Desde esta perspectiva, tanto las ideas de turismo cultural como las de turismo patrimonial involucran el consumo de bienes culturales, lo que reproduce una de las bases del desarrollo del PPM: poner en el mercado bienes culturales para su consumo, lo que se hallamado la mercantilización de la cultura.

En su análisis de los "Alardes" de Fuenterrabía, Greenwood (1989) ya señalaba la tendencia de las actividades turísticas de poner en la esfera del mercado aquellos bienes y prácticas culturales que se encontraban fuera de este; señalaba también el peligro de que estos bienes se banalizaran, mediante estrategias que modificaran las festividades para satisfacer las necesidades y demandas de los turistas. El análisis de los procesos de mercantilización de la cultura ha generado numerosos estudios, y entre estos consideramos que la propuesta de Gotham presenta de manera sintética sus principales rasgos: "La mercantilización refiere al dominio del valor de cambio de la mercancía sobre su valor de uso, e implica el desarrollo de una sociedad de consumo donde las relaciones de mercado subsumen y gobiernan la vida social" (Gotham, 2007:310, traducción propia.). Esta aproximación no guarda gran diferencia con otros acercamientos como los de López Santillán y Marín Guardado (2010) o el de Cahyadi (2016), por mencionar algunos. La mercantilización cultural en Izamal se ha mantenido en estrecha conexión con la identificación de ciertos bienes culturales relacionados, fundamentalmente y en orden de importancia, con el patrimonio edificado (prehispánico y colonial), las artesanías y la comida, bienes pertenecientes a la cultura maya-yucateca.

La estrecha relación que se construye entre la mercantilización de la cultura y sus consumidores por excelencia, los turistas, conlleva una serie de procesos entre los que destaca la autenticidad. Identificamos la autenticidad como un proceso y no solamente como un resultado, toda vez que siempre está en continuo movimiento e implica un trabajo permanente de construcción, mantenimiento y regulación (Cobb, 2014). Esta construcción se organiza sobre la siguiente lógica:
Las prácticas y objetos culturales más auténticos pa- recen ser aquellos que no solamente imitan fielmente un conjunto de prácticas y objetos heredados, sino que también se producen en una localidad específica, por un tipo específico de gente y para un objetivo especí- fico, objetivo que no está conectado con los procesos mercantiles. [...] para ser genuinamente auténtico, esta reproducción debe tener lugar fuera del proceso de intercambio, es decir, fuera de la supuesta racio- nalidad de cálculo de los mercados y asegurada en el terreno del valor de uso natural desde la perspectiva de Marx (Shepherd, 2002:192).

Sin embargo, es esta misma ubicación fuera del mercado la que hace más atractiva su incorporación, al mismo tiempo que dota a los bienes culturales del aura necesaria para entrar con ventaja en el mercado turístico.

La autenticidad es "un valor eminentemente moderno, cuya emergencia está cercanamente relacionada con el impacto de la modernidad sobre la unidad social" (Cohen, 1988:373). La autenticidad no puede ser tomada como una cualidad objetiva del mundo exterior, puesto que en realidad es una construcción social dinámica que se nutre de las visiones y discursos (cambiantes y en ocasiones en disputa) de diferentes actores. Sin embargo, la búsqueda de la legitimidad obliga a la elección parcial o completa de procesos u objetos que se conciben como esenciales, desechando otros con la intención de declararlos tácitamente como inauténticos. En el caso de la industria turística, la autenticidad se construye por la negociación tanto de locales, como de turistas y de intermediarios. Es un tipo de autenticidad constantemente renovada y moldeada, dado que tanto algunos actores locales como los turistas desempeñan un papel importante en su construcción. 
Del trabajo de construcción de la autenticidad se encargan numerosos agentes que, directa o indirectamente, intervienen generando diversas estrategias, entre las que se encuentra la construcción de la mirada turística, de los imaginarios turísticos y de la imagen turística, tres modalidades que refieren fundamentalmente a un mismo proceso pero que manifiestan distintos énfasis.

La proliferación de imágenes visuales en la sociedad contemporánea es un hecho por demás evidente, y en el caso del turismo estas juegan un papel relevante en su propia práctica. La idea de sightseeing, término empleado casi como sinónimo de prácticas turísticas, refiere y realza el papel de la vista como el sentido privilegiado de una actividad que se centra en contactos visuales y en consumos visuales de museos, de centros históricos, de paisajes, de territorios, de prácticas y performances culturales, entre otros (Adler, 1989).

Otra arista de igual importancia en torno a las imágenes visuales tiene que ver con la posición epistemológica de la vista como criterio contemporáneo de verdad (Adler, 1989). Lo que pasa a través de nuestra vista es considerado como verdadero, y aunque esta situación ha variado históricamente, el privilegio de la vista como sentido se manifiesta hoy día como mecanismo de contraste entre las palabras y la realidad: "ver para creer".

El papel de la vista y de la posición que la mirada tiene en el turismo debe a Urry (1990) una de sus primeras aproximaciones. La entendemos como el conjunto de dispositivos y agentes que determinan y distinguen lo que es bueno para ver, turísticamente hablando, de lo que no lo es, guiando y estructurando la mirada hacia ciertos lugares, personas y procesos en un marco histórico y socialmente determinado, por lo que esperamos transformaciones relacionadas directamente con esta situación.

Igualmente importante es señalar que, si bien hay una prevalencia de la vista sobre otros sentidos en la construcción de la mirada turística, esta no se lleva a cabo sino en armonía con un discurso escrito. La consonancia es fundamental, pues el discurso visual o audiovisual no se contrapone al escrito, más bien lo fortalece. En este sentido, la mirada puede ser considerada como un campo epistémico producido visual y lingüísticamente (Urry y Larsen, 2011). ${ }^{5}$
En lo que refiere a los imaginarios turísticos damos cuenta de la aproximación de Salazar, quien los entiende "[...] como ensamblajes de representaciones transmitidos socialmente, que interactúan con los propios imaginarios de la gente y se emplean tanto como productoras de significado como dispositivos que moldean el mundo" (Salazar, 2012:864). Con esta propuesta se incorpora la agencia de los turistas para contribuir a la producción de la imagen turística. Atiende también la necesidad de incorporar en el análisis de los imaginarios, su circulación, la infraestructura que le permite propagarse, su capacidad de ajustarse a diferentes contextos y su competencia con otras ideas e imágenes que circulan por igual (Salazar, 2012). En el mismo tenor, Adams (2004) ya había señalado que desde la génesis de la conformación del imaginario turístico entraron en competencia distintas imágenes, producidas tanto por locales como por extranjeros.

En un marco relacionado con el ejercicio del turismo como estrategia comercial, se ha analizado la imagen turística desde su complejidad y su carácter multidimensional. Algunos autores (Álvarez de la Torre y Rodríguez-Toubes, 2013; Camprubí, Guia y Comas, 2009; Gallarza, Gil y Calderón, 2002; Nicoletta y Servidio, 2012) se han enfocado en gran medida en lo que podemos llamar mercadeo (marketing) turístico; con ello quieren ver la eficiencia de las imágenes turísticas (emitidas/inducidas) y sus efectos (imágenes percibidas) en los consumidores, presentes y futuros. Su aproximación es fundamentalmente cuantitativa y analizan cuestiones tales como los logos empleados para la promoción turística de un país (Lee, Rodríguez y Sar, 2012), las tarjetas postales (Yüksel y Akgül, 2007), las fotografías publicitarias (Donaire y Galí, 2011; Galí, 2005; Santillán 2010) y los programas de la televisión comercial (Iwashita, 2006), entre otros.

No obstante, el énfasis en la eficiencia del impacto de las imágenes turísticas en sus futuros clientes, señalada en las propuestas anteriores, tiene puntos de coincidencia entre ellos en cuanto a que las imágenes turísticas compiten unas con otras, que los medios e infraestructuras son fundamentales para la circulación de dichas imágenes y que hay un importante nivel de 
agencia del turista para comprender y recomponer la imagen turística a partir de sus experiencias previas.

Considerando esta situación, lo que pretendemos analizar de manera particular es cómo, a nivel local, se refuerza o debate la imagen turística de un destino en las interpretaciones y responsabilidades de los agentes cuya función es justamente diseminarla. Así, el artículo se centra en agentes cuya posición en el sistema turístico es relativamente débil, pero da cuenta de cómo el imaginario turístico se puede fortalecer o debilitar, no únicamente en el proceso de emisión sino también en el proceso de transmisión o transferencia a los turistas. Para poder hacer esto, conviene presentar algunos de los rasgos centrales de la imagen turística de Izamal, para reflexionar posteriormente acerca de las ideas de nuestros colaboradores.

\section{Contexto y componentes de la imagen turística de Izamal}

Izamal es uno de los 106 municipios que conforman el estado de Yucatán. Tiene una superficie de 460.02 kilómetros cuadrados, ocupada por sus seis localidades: Izamal (cabecera municipal), Citilcum, Sitilpech, Xanabá, Cuauhtémoc y Kimbilá. ${ }^{6}$ Tiene una población de 26801 habitantes (de los cuales 16195 se localizan en la cabecera municipal), según la Encuesta Intercensal 2015 realizada por el Instituto Nacional de Estadística y Geografía (INEGI). En lo referente a características de la economía local, según datos del censo 2010 del INEGI, 10054 personas están ocupadas en algún sector de actividad económica. Del total de personas ocupadas, 1449 se dedican a actividades primarias, 5962 se dedican a actividades del sector secundario y un total de 2577 se dedican a actividades del sector terciario. Según el mismo censo, la población de cinco años o más, hablante de lengua maya, es del 34\%. Cuenta con una excelente comunicación vía terrestre, condición necesaria para ser considerada como pueblo mágico.

El municipio de Izamal formó parte de la agroindustria henequenera del estado de Yucatán. La revolución industrial y la introducción de máquinas de vapor en la década de 1890 permitieron en el estado la producción de henequén a gran escala, con lo que dominó el mercado mundial. En Izamal, durante el último tercio del siglo XIX, las antiguas haciendas maicero-ganaderas comenzaron a centrar su sustento en la siembra del henequén. Debido al precio que llegó a tener esta fibra, se consiguieron importantes mejoras materiales en la localidad, como la inauguración del ferrocarril en 1890 , escuelas, teléfonos, telégrafos, periódicos, teatros como el Justo Sierra y agrupaciones culturales (Vera, 2018:86). Durante la década de 1920, esta industria yucateca entró en decadencia debido a la baja del precio del henequén, al encarecimiento de la mano de obra (peones mayas trabajaban en condiciones de cuasi-esclavitud hasta la llegada de Salvador Alvarado) y a la pérdida del estatus de Yucatán como único productor y comercializador de la fibra de henequén (Canto, 2001).

La economía en el estado volvió a consolidarse tras la creación en 1961 de Cordemex, S.A. de C.V., empresa de participación estatal, cuyas acciones estuvieron divididas entre los empresarios cordeleros (a la par que disminuían las exportaciones de la fibra de henequén, aumentaba su consumo por las cordelerías locales) y el gobierno federal, hasta que en 1964 los empresarios vendieron sus acciones a la federación (Canto, 2001). El resurgimiento del auge económico en Yucatán no duró mucho, ya que el 9 de abril de 1991 Cordemex concluyó formalmente sus labores.

Las políticas neoliberales impulsadas en México desde los años noventa del siglo pasado implicaron reducciones del subsidio a la producción henequenera en 1984, pasando por la individualización del ejido y la indemnización a los ejidatarios henequeneros de 1992 que pusieron punto final al apoyo gubernamental a esta industria. Estas medidas vinieron acompañadas del impulso a otras actividades productivas (Baños, 2010; Castilla, 2004). En Izamal, esto se vio reflejado en la apertura de maquiladoras, ${ }^{7}$ y posteriormente en una apuesta más decisiva hacia el turismo como estrategia de desarrollo local. ${ }^{8}$

En la actualidad la economía de Yucatán se ha terciarizado. La crisis económica ocasionada por la debacle de la producción agropecuaria ha visto una solución en el turismo, que se ha planteado como una 
alternativa laboral para enfrentar la difícil situación. Las autoridades utilizaron el patrimonio natural y cultural de Yucatán como una potencial fuente de atractivo para convertir al estado en un destino turístico bajo la etiqueta de "mundo maya" (Córdoba, 2009). Es en este contexto donde se produce la solicitud e incorporación de Izamal al PPM, en lo cual trabajaron distintas instancias para su consecución. ${ }^{9}$

Izamal es conocida ampliamente por ser el santuario de la virgen de la Concepción, patrona de Yucatán, y por albergar la iglesia con el atrio cerrado más grande de Latinoamérica. Desde la época prehispánica ya era considerada un santuario y recibía numerosas peregrinaciones a lo largo del año para honrar a Izamná (Itzam Na Thul o Itzam Na), que en español significa "el que recibe y posee la gracia o rocío y sustancia del cielo" (Lizana, [1893]1995) y de donde toma su nombre la población. En este sentido, la población tiene una gran experiencia en recibir peregrinos, por lo que podríamos sostener que el llamado turismo religioso ha sido una constante en el paisaje izamaleño, ya que, como señalaran Turner y Turner (1978), hace ya bastantes años, las diferencias entre turistas y peregrinos es porosa. ${ }^{10}$ En Izamal el turismo religioso está compuesto por personas de diferentes partes del estado de Yucatán y de los estados vecinos de Campeche y Quintana Roo, es en este sentido un santuario regional (Fernández y Negroe, 1997 y 2006) visitado especialmente durante las fiestas del Cristo de Sitilpech que se realizan en el mes de octubre, y de la virgen de la Concepción que se celebra en diciembre (Alvarado-Sizzo, 2016; Alvarado-Sizzo, Propin y Sánchez, 2017, Tzuc, 2018). De manera preferente, tanto los turistas religiosos como los culturales o patrimoniales recorren el convento de San Antonio de Padua, el ayuntamiento, las distintas calles que exhiben las casonas coloniales y el resto de las edificaciones que conforman el centro histórico de la ciudad, e incluso algunas viviendas fuera de este espacio cuando visitan los talleres artesanales, todas ellas adornadas del característico color amarillo izamaleño, y no dejan de visitar los vestigios arqueológicos, principalmente Kinich Kak Moo. ${ }^{11}$
No obstante, a pesar de los esfuerzos continuados de las autoridades en todos sus niveles y de la iniciativa privada, Izamal sigue siendo receptora de un turismo "de paso", siempre en camino hacia otro destino de mayor importancia, como Mérida o Cancún, y eso se refleja en el porcentaje de ocupación hotelera durante 2019, que fue de solamente el $24.97 \%$ en promedio. ${ }^{12}$ Pero no por ello abandonamos nuestras intenciones académicas, pues la ciudad continúa siendo un referente turístico de importancia para el estado y para la región.

\section{La imagen turística}

La promoción turística de Yucatán se ha enfocado en el llamado turismo cultural. Las primeras imágenes escritas y visuales de la región que circularon en el mundo se debieron a las publicaciones de John L. Stephens, quien en los dos volúmenes de Incidents of Travel in Yucatan difundió, a mediados del siglo XIX y de manera profusa, la existencia de la civilización maya. En estos volúmenes se da cuenta y se describen diversos sitios arqueológicos y numerosas prácticas culturales de la región. Mientras que las imágenes escritas estuvieron a cargo del propio Stephens ([1843]1963), las ilustraciones insertas en ambos volúmenes fueron realizadas por Frederick Catherwood. Otros viajeros visitaron Yucatán durante el mismo siglo e igualmente reportaron la existencia de esa maravillosa civilización; ellos fueron personajes tales como Frédéric de Waldeck, Emmanuel von Friedrichsthal y Le Plongeon, entre otros (Depetris, 2015). Channing Arnold y Tabor Frost participaron también en esta difusión con la publicación de su libro The American Egypt: A Record of Travel in Yucatan, en el que comparan la grandeza de la civilización maya con la de Egipto (Arnold y Tabor Frost, [1909]2014). En estos trabajos Izamal está siempre presente. En tal sentido, los bienes culturales referidos a Yucatán que se diseminaron por el mundo occidental se circunscribieron a lo que hoy se ha denominado, no sin controversia, el patrimonio cultural tangible e intangible del estado.

Son varios agentes los que han configurado la imagen turística de Izamal, sus trabajos de promoción despliegan la acción concertada del gobierno federal, 
el gobierno del estado de Yucatán, el ayuntamiento de Izamal, la Fundación Haciendas del Mundo Maya, la Fundación Pedro y Elena Hernández, A.C. y Fomento Cultural Banamex..$^{13}$ La mayor parte de los folletos elaborados por estas instancias toman como eje el convento de Izamal para de ahí partir a otros sitios de interés (ver Imágenes 2, 3 y 4 ).

Hoy en día circulan en diversos medios (folletos turísticos, guías de viajeros, páginas de internet) cinco imágenes que enfatizan diversos aspectos de la localidad; desde la más antigua y conocida hasta las más recientes, se relacionan las siguientes: "Ciudad de las tres culturas", que refiere a la integración del pasado prehispánico y colonial, inscrito en el presente, y a la continuidad histórica; "Ciudad de los cerros", que enfatiza el pasado prehispánico destacando los montículos o pirámides de la ciudad, de ahí el apelativo; la "Tres veces santa", que apela a su pasado y su presente religioso; "Una ciudad pintada de amarillo", que destaca el color del patrimonio construido, particularmente el centro histórico, y por último, "Izamal, ciudad luz", nombre que se debe al desarrollo de un espectáculo de videomapping dentro del proyecto Senderos de Luz. ${ }^{14}$ Siguiendo las ideas de Bruner (2005) podemos señalar que, de estas cinco imágenes, se alude respectivamente a la integración cultural y social en un marco de continuidad, al nacionalismo de raíces prehispánicas, a la colonización espiritual, al pasado colonial y terrateniente que exalta el patrimonio edificado a través de un color y a la conjugación de tradición y modernidad con la puesta en escena de un pasado prehispánico y colonial, mediante un medio moderno de comunicación, el videomapping.

La relación entre estas imágenes no se corresponde con las imágenes visuales que también circulan en los medios señalados anteriormente, pues estas últimas enfatizan de manera preponderante el convento de san Antonio de Padua. Podría afirmarse que esta imagen funciona como la oficial de la ciudad. La presencia de los vestigios arqueológicos, algunas calles del centro histórico, las artesanías y la gastronomía yucateca se conjugan con el convento para ampliar la imagen. Observamos, sin embargo, que el tiempo presente queda fuera, no hay imágenes visuales de la modernidad; se reconoce como una de las tres culturas, pero se opaca junto con las personas que no visten el traje típico yucateco. Todo ello para legitimar la autenticidad del producto turístico. ${ }^{15}$

La autenticidad se manifiesta en las formas pasadas de ser, alejadas de la modernidad, que queda reflejada en las imágenes que aluden a la tranquilidad de la localidad, con sus calles semidesiertas, con una marcada ausencia de las actividades cotidianas de la población local, una imagen que pone por delante lo auténtico por encima de cualquier alternativa, invisibilizando a los pobladores para mantener la imagen impuesta por y hacia el turismo. Así, mediante la visibilización selectiva de ciertos actores en ciertos momentos, se construye no solamente una imagen que "inventa" o por lo menos parcializa la realidad, sino que también se fortalece una idea romantizada de Izamal, una ciudad (pueblo mágico) que reverbera en su pasado para darle forma y hacer su presente en torno al turismo (Urry, 1990).

La imagen descrita anteriormente se reitera en varios sitios de internet. El sitio de internet denominado " $5 \mathrm{Im}$ prescindibles para disfrutar de Izamal, Pueblo Mágico"16 hace lo propio a través de la propuesta de ciertas rutas que deben ser transitadas para acercarse a la autenticidad de la localidad, por lo que emplea imágenes visuales que dan fuerza a la misma idea.

Los imaginarios construidos de Izamal se enfrentan a otros más que han sido invisibilizados; ya mencionamos uno de ellos, la modernidad. Otros más, que forman parte innegable de la historia de la ciudad, han sido silenciados, entre ellos, los regímenes cuasi-esclavistas que caracterizaron a la producción henequenera representados en las grandes casonas de la ciudad y de la capital de Yucatán (Fernández, 2015), la presencia de las maquiladoras como parte de los proyectos de desarrollo regional, la pobreza de la periferia de la ciudad, y el discutible legado de personajes tan controversiales como fray Diego de Landa (Benavides, 2013). No son necesariamente imágenes en competencia, según los términos de Salazar (2012) y de Adams (1997 y 2004), pero sí muestran que la imagen turística procede de una selección de objetos, términos y pasajes de la historia con la finalidad de 
crear una historia neutra que elimina conflictos y rencores (Salazar, 2006). Sobre esta imagen neutra vale la pena presentar cómo la narración en el videomapping se elabora sobre esta base:

Izamal, tierra de hombres trabajadores, de manos firmes y honestas, manos que enaltecen la nueva vocación turística para el disfrute de propios y foráneos. Tierra que fusiona el pasado con el presente, donde al caminar por sus calles se ve la arquitectura e historia que ha prevalecido a través del tiempo y hoy renace con un resplandor restaurado [...] Vestimentas que demuestran el trabajo artesanal como el hipil, sombreros, colorido y tradición, todo esto es el orgullo de ser yucateco, izamaleño. Los colores de las fiestas patronales alegran el lugar y la jarana se escucha tocar. Izamal donde la historia prehispánica, colonial y el presente viven. Lugar de las tres culturas (Narración del videomapping, Senderos de Luz, escuchado el 19 de marzo de 2016).

Si el convento de san Antonio de Padua, las pirámides, los talleres artesanales, incluido el Centro Cultural y Artesanal, son los referentes centrales que de manera constante componen la imagen turística de Izamal, corresponde ahora analizar cómo se reitera o aparta esta imagen en las voces de los guías turísticos locales que de manera directa transmiten a los turistas.

\section{Los guías turísticos locales}

Los guías locales certificados ofrecen sus servicios a los turistas durante las visitas de estos últimos sin ningún acuerdo previo. ${ }^{17}$ Entrevistamos a dos de los tres que ofrecen sus servicios, Julio y Javier, jóvenes treintañeros, originarios de Izamal y maya-hablantes, para abordar su participación en la producción o reproducción de la imagen turística de Izamal.

La experiencia laboral de Julio en el ramo turístico es amplia; trabajó en Cancún por muchos años, fue mesero en varios restaurantes de Izamal y considera que: "De hecho, yo, mi fuerte es más la gastronomía” (Julio, 15 de mayo de 2016). En el mismo ramo turístico, trabajó como calesero $^{18}$ hasta 2015, cuando tuvo la oportunidad de tomar un curso que derivó en su formación como guía de turistas. Para ese trabajo debe tener ciertas habilidades comunicativas, tanto para acercarse a los turistas como para venderles las visitas guiadas. Señala la necesidad del continuo estudio de la historia, la cultura y la arquitectura de Izamal, pues solamente así puede responder a las preguntas de los turistas y ofrecer lo que él supone que es un recorrido completo. "Actualmente yo diario leo media hora, ya sea mi manual, ya sea otras cosas nuevas, ya sea en la biblioteca, ya sea preguntando a la gente antigua, a la gente grande", afirma este guía (Julio, 15 de mayo de 2016).

Hablar de Izamal es algo que ha hecho con mucha satisfacción y orgullo, el interés de la gente por su localidad le provocaba contar historias de esta, basadas sobre todo en "lo que dice la gente" y no tanto en lo que había estudiado.

Me gusta mucho conocer opiniones de la gente, me gusta ver cómo después de platicarles las anécdotaso leyendas o algún caso importante, la gente se va muy contenta. Se va muy interesada, más que nada viene mucha gente muy interesada acá a Izamal, entonces pues eso me orilló a estar trabajando actualmente de guía (Julio, 15 de mayo de 2016, énfasis añadido).

La imagen turística que se busca transmitir in situ toma elementos tanto de la instrucción formal, como de los conocimientos otorgándoles la misma importancia. De esta manera se reconocen las fuentes de los saberes especialmente de las "personas antiguas", con la misma validez que la que tienen tanto los textos históricos y arqueológicos como los que provienen de la población local. En cierto sentido, su trabajo es una especie de recuperación y rescate de conocimientos e historias locales, que son importantes para darle un toque único a Izamal. Se trata de un reconocimiento local de autenticidad que se sostiene sobre las mismas bases que se aplican en otros contextos, la experiencia y la historia; el reconocimiento se extiende también a una idea de patrimonio intangible que no se materializa como tal en su discurso, pero que está presente 
como fuente constante de conocimiento y saber (ver Imágenes 4 y 5 ).

Javier ha vivido toda su vida en Izamal. Debido a las actividades de su padre, el reconocido artesano Esteban Abán Montejo (miembro del programa Grandes Maestros del Arte Popular Mexicano de Fomento Cultural Banamex), desde temprana edad tuvo un fluido contacto con turistas que consumían los productos artesanales de su padre.

El interés de los turistas por visitar diferentes sitios de Izamal provocó que Javier se interesara por desarrollarse como guía de turistas. "Los visitantes me decían [preguntaban] a dónde ir a visitar. [...] Y yo les comentaba otro lugar... Y a veces me decían: y ino nos acompañas? para que nos digas por dónde es, para que no nos perdamos y para que sea un poco más rápido, y les acompañaba" (Javier, 21 de mayo de 2016).

Tanto Julio como Javier tomaron el mismo curso de certificación de guía de turismo en 2015. Como parte de los resultados de este curso, se encuentra la infundida necesidad de continuar preparándose para mejorar su trabajo. Cuando en abril de 2019 regresamos a Izamal para entrevistar nuevamente a Julio, él señaló los diversos cursos que recientemente había tomado para actualizarse, en particular en arqueología.

Javier, por su parte, sostiene que ser guía turístico es una actividad que no se reduce a las visitas guiadas, pues para llevarlas a cabo tienen que actualizarse de manera continua, deben diversificar su trabajo con nuevos paseos turísticos; para ello: "Más que nada escuchar a las personas mayores, por ejemplo, entre esos están los abuelitos y el cronista de lo que es Izamal. A veces tiene mucha información que uno no sabe" (Javier, 2l de mayo de 2016). En este caso, Javier conjuga el conocimiento local que se mantiene en la esfera de lo arbitrario (en la voz de los abuelitos) con el conocimiento legítimo (en la voz del cronista de la ciudad) (Bourdieu, 1973).

Ambos guías sostienen que las personas mayores tienen mucho conocimiento, que saben cosas que son de interés para los turistas, y al mismo tiempo consideran que estos conocimientos pudieran ser de interés para la población local. Pero reconocen que, si no fuera por su trabajo en el turismo, quizás ellos tampoco estuvieran interesados, como pasa con la población contemporánea de Izamal. Ello apunta a una especie de oscuridad sobre la relación entre la población y el patrimonio intangible, y en otra dirección a sobrevalorar el patrimonio tangible, particularmente el construido, como el más importante para la generación de recursos económicos.

En su percepción, ambos reconocen que el turismo que llega a Izamal es de paso. "Solo vine a conocer Izamal, tomarme una foto y me estoy yendo a Chichén o me estoy yendo a Playa [Playa del Carmen] o me estoy yendo a Mérida. Izamal es un pueblo de paso para la gran mayoría de los turistas", ejemplifica uno de los entrevistados (Julio, 15 de mayo de 2016). La idea, desde el punto de vista de este guía, se debe al imaginario con el que los turistas llegan. "Tienen un concepto de Izamal como si fuera nada más un pueblito en el cual no hay servicios, no hay atractivo más que el convento" (Julio, 15 de mayo de 2016). En la entrevista realizada en 2019, agregó: "Es el concepto que tienen en su mente, que aquí en Izamal no hay nada. Que Izamal es un pueblo cuando realmente no, Izamal tiene historia, solo caminando por sus calles te enriqueces" (Julio, 23 de abril de 2019). Esta idea se fortalece con los imaginarios promovidos de Izamal, centrados como hemos visto en el convento y el sitio Kinich Kak Moo. La imagen turística de la ciudad es entonces estrecha, después de la visita a ambos monumentos no queda nada, los turistas pueden estar satisfechos, han conocido lo que debían de conocer.

Para Javier lo que caracteriza a esta ciudad es su color amarillo, el convento y sus basamentos prehispánicos, y describiría Izamal como "una ciudad muy bonita y cuando llegues vas a ver todo, vas a ver el centro histórico y las calles principales de color amarillo [...] Yo les defino así a Izamal, una ciudad muy bonita de color amarillo" (2l de mayo de 2016).

Desde la perspectiva de Julio, la ciudad no ofrece atractivos para todo tipo de turistas: "Para los chavos no es un buen lugar Izamal porque es más cultural, es más religioso. Para la gente grande es un buen atractivo, para la que quiere conocer, que quiere aprender y ver cómo se vivía hace mucho tiempo" (15 de mayo de 2016). Incluso la apertura de bares u otros lugares pensados en función de esta población no los atraería, 
pues Izamal está consolidada como un lugar tranquilo y para el descanso, lo que quiere ver el turismo es "cómo se vivía hace mucho tiempo", presentando con ello una visión "alocrónica" de la realidad temporal de la ciudad (Fabian, 2002). También considera que la ciudad recibe más turistas europeos porque ellos están interesados en la cultura, son parte del turismo cultural. ${ }^{19}$

En contraste con Julio, Javier piensa que su posición como pueblo mágico convierte a Izamal en un destino para cualquier visitante:

Conocer lo que es un pueblo mágico, hay muchos pueblos mágicos, muchos lugares pintorescos, muchos lugares con mucha historia, con muchas leyendas, pero Izamal no se queda atrás en cuestión de estas cosas especiales. Izamal es especial por su historia más que nada y por la forma de ser de sus habitantes (personas tranquilas, atentas, respetuosas) que es lo que hace que pases un rato agradable (Javier, 21 de mayo de 2016).

Estar en la ciudad "sería como que detuvieras el tiempo, en un instante, en un momento. He visitado otros lugares y me he sentido que llegas a lugares que como sin querer se detiene el tiempo y uno de esos sería Izamal" (Javier, 21 de mayo de 2016), y "la denominación de pueblo mágico es por las ciudades o pueblos que conservan su cultura, sus tradiciones y en este caso pues la belleza arquitectónica" (Javier, 15 de mayo de 2016). Los guías incorporan los lineamientos del PPM ${ }^{20}$ en la construcción de su discurso. La magia de Izamal se basa en el mantenimiento y la recuperación continua del pasado que se conjuga con el presente. Esta conjunción es la que se presenta a los turistas y la que reitera la imagen turística. Con estas ideas puede observarse que ambos guías confieren gran importancia al pasado de la ciudad y apelan a un tipo de turismo de nostalgia, como su principal consumidor.

La incorporación de Izamal como pueblo mágico transformó las tradiciones izamaleñas en productos turísticos para consumo de los visitantes. Esta transformación consistió fundamentalmente en ampliar y profundizar, en la medida de lo posible, la distancia entre las tradiciones y las prácticas modernas; un caso significativo en esta dirección lo constituyen las artesanías, actividad en la que se recuperaron objetos y bienes distinguidos como locales o de origen prehispánico para ser incorporados al mercado turístico. Desde el punto de vista de Julio, el turismo es una forma importante para recuperar y revalorar las tradiciones que, según él, se están perdiendo: "Viviendo de la forma tradicional puede ser un atractivo turístico. Que la gente venga a ver cómo vive la gente, cómo hace sus actividades cotidianas, la comida. Puede ser un atractivo" (15 de mayo de 2016). Más que oponer un nosotros versus los otros en el plano contemporáneo (Salazar, 2006), se establece una oposición entre tradición y modernidad; conservar la tradición es mantenerse en el pasado, generando el atractivo suficiente y necesario para sostenerse como destino turístico y apegarse al mismo tiempo a los requerimientos del PPM. No por ello la tradición se convierte necesariamente en un simulacro (Baudrillard, 1977), o en una autenticidad escenificada (MacCannell, [1976]1999), se trata de personajes locales que han reparado en sus propias condiciones.

Por su parte, Javier considera que las tradiciones no se están perdiendo, sino que se están actualizando:

Ya las guayaberas ya las están modernizando, ya los hipiles igual, hasta cierto punto como que te los medio actualizan. El idioma igual, ya lo están... Los chavos ya lo están sacando en rap. Entonces es algo bueno porque como que se vuelve a retomar, como que se le da algo clásico, algo antiguo, pero a la moda (Javier, 21 de mayo de 2016).

Si bien Javier reconoce que a pesar de los cambios las tradiciones conservan su esencia, las tradiciones actualizadas no son atractivas pues lo que el turismo busca es el pasado inscrito en el presente. "Los visitantes vienen a Yucatán para ver mayas. Lo primero que quieren ver es a un maya: 'quiero ver un maya, quiero escuchar el idioma maya, quiero ver cómo vestían, qué comían, cómo pensaban, qué hacían, cómo se divertían"' (Javier, 21 de mayo de 2016). Acorde con esta búsqueda, Julio ofrece sus servicios de guía en el atrio del convento; para ser identificado rápidamente por sus posibles 
clientes, porta su credencial de guía y construye su propia imagen alrededor de la idea de un yucateco/ maya $^{21}$ contemporáneo, por eso viste de guayabera, porta un sabucán de henequén, ${ }^{22}$ usa xana'k'ewel (es) ${ }^{23} \mathrm{y}$ un sombrero de jipi. ${ }^{24}$ Con ello, no solo busca exponer su identidad a los turistas sino también dar autoridad y autenticidad a su discurso.

Las visitas guiadas se realizan a varios puntos de la ciudad; en primerísimo lugar, al convento franciscano, para después visitar las iglesias, los edificios prehispánicos, los talleres artesanales, los parques y los restaurantes. Las visitas inician con unas preguntas: “¿Quéles gustaría hacer? ¿Qué les gustaría conocer de Izamal? Y ellos me preguntan qué es lo que hay. Yo les digo que hay basamentos, está el convento, hay talleres artesanales, hay capillas y hay parques" (Javier, 21 de mayo de 2016). La delimitación de los atractivos se conforma a la imagen turística del lugar, por lo menos en esta fase inicial del recorrido. La respuesta más recurrente es que “(quieren) conocer un poquito más de lo que fue Izamal antes y más que nada visitar el convento y el basamento Kinich ${ }^{25}$ y un taller en específico" (Javier, 21 de mayo de 2016). "Nosotros les hacemos interesante el recorrido porque ellos no se imaginan lo interesante que es el lugar hasta que uno se los platica... Yo creo que [es] más lo maya [lo que les interesa]" (Julio, 15 de mayo de 2016). Tanto Julio como Javier consideran que el pasado de Izamal representa el principal atractivo para los visitantes, que genera la atracción, y aunque Julio se viste como local para atraer clientes, habla de lo maya como algo relativamente externo a él (Salazar, 2005).

La manera de hacer los recorridos varía; puede realizarse a pie, en bicicleta, en calesa o en automóvil. Javier señala que la última opción no la recomiendan, pues de ese modo los turistas "no conviven" con Izamal y tampoco dejan beneficio económico a la población.

Yo preferiría que rentaran la bicicleta o calesa o caminando. Son los tres que preferiría porque si vamos caminando se van a cansar, les va a dar ganas de tomar agua, comer algo y lo hacemos en el camino. Entonces pasamos a una tiendita, compramos agua, algunos panes, algo así por el estilo, y conviven con el pueblo de lo que es Izamal. En cambio, si van en su propio auto no van a convivir con Izamal y sólo vamos a los sitios arqueológicos, subimos y bajamos (Javier, 21 de mayo de 2016).

La idea de la convivencia se da en un doble sentido; por un lado, se habla de una convivencia con Izamal, como si su referencia remitiera al establecimiento de una relación con el patrimonio prehispánico y colonial de la localidad, y por el otro remite a la generación de contactos intermitentes con la población local a partir de intercambios económicos, que son también pretextos para generar conversaciones con y sobre la localidad y su gente. Esta posición revela, sí, un particular alejamiento de la imagen turística, pues propone la necesidad de un mínimo de convivencia para conocer realmente el lugar y sus aspectos más auténticos.

El pasado conjugado con el presente se presenta como "auténtico", legitimado por el tiempo y por la historia. "Ahora las personas, los jovencitos, practican, les agrada, les gusta más que nada. De todo, en gastronomía, forma de vestir, forma de expresarse, juegos [...] Por ejemplo, en mi caso, que yo hago el $p i b,{ }^{26}$ sesenta por ciento lo hago como para recordar a mi ser que ya se fue, y el otro cuarenta por ciento lo hago como una entrada de dinero" (Javier, 21 de mayo de 2016).

Otro ejemplo que refuerza esta idea lo señala Javier:

A nosotros nos han llegado muchos españoles que quieren la purificación. Más que nada ellos quieren como un tipo, le llaman limpia, pero es una purificación más que nada y lo quieren que sea un chamán y lo quieren que sea en maya. Aunque ellos no entiendan lo que esté diciendo, pero lo quieren, más que nada se sienten las vibras, las emociones. Hay muchas personas que están conectadas con la naturaleza más que uno mismo y sienten esas emociones (Javier, 21 de mayo de 2016). ${ }^{27}$

De esta manera, actúan acordes con la mirada e imagen turística reconstruyendo una cultura maya exotizada y autentificada por la tradición, en la que tautológicamente tradición y autenticidad se sostienen la una a la otra: 
por ser tradición es auténtica y es auténtica porque es tradición (Salazar, 2006).

En esta misma búsqueda de lo auténtico, Julio reconoce que la "profecía maya del fin del mundo" incrementó el número de visitantes en 2012. "Fue una locura que en Izamal nunca había yo visto tanta, cuando hay gente acá en Izamal hay para todos, para el Kinich, Los Mestizos, para El Toro, El Muul, ${ }^{28}$ para los coches caballitos, los venteros, para los artesanos..." (Julio, 15 de mayo de 2016).

De la imagen turística de Izamal, y de los discursos de Javier y Julio, pueden extraerse por lo menos tres elementos relevantes. El primero refiere a una especie de concreción de la magia, como cuando Javier señala que "al visitar uno a Izamal se encuentra con un pueblo muy pintoresco, muy alegre, muy cómodo, muy seguro, el aire se siente diferente" (Javier, 21 de mayo de 2016). Esta concreción se expresa desde nuestro punto de vista en una idea de turismo experiencial o posmoderno (Cohen, 2005; Morgan y Pritchard, 2005; Urry, 1990) que enfatiza la experiencia sobre otros aspectos del viaje, pero que también remite a una sensación cuya manifestación impacta los sentidos y solamente la metáfora puede dar cuenta de ella. Julio emplea otras metáforas sobre esta misma idea, como cuando señaló que "Izamal es pasado, misterio y energía", y apelando al sentido del olfato, indicó que "Izamal es una ciudad por el número de habitantes, pero parece un pueblo, tiene aroma a pueblo" (Julio, 23 de abril de 2019).

El segundo coincide con el carácter único y singular, típico de la conformación de las imágenes turísticas, trata de particularizar las condiciones de la localidad a partir de la conjugación de tiempo, espacio y sensaciones; así, Javier señaló: "No va a encontrar otro pueblo similar a este. Por ejemplo, yo he visitado otros pueblos mágicos y están bonitos, están hermosos, pero comparándolos con Izamal, no es lo mismo" (Javier, 2l de mayo de 2016). Misterio y pasado se funden y confunden, apelando al descubrimiento (Hervik, 1999), mientras que esta misma amalgama genera sensaciones vitales y de tipo new age, similares a las visitas a distintos sitios turísticos que muchos turistas realizan para recargarse de energía (Himpele y Castañeda, 1997).
El tercero tiene que ver con una oposición entre pueblo (tradición) y ciudad (modernidad). Esta idea coincide con la perspectiva del PPM, considerando que solamente en los pueblos se mantienen las tradiciones y la esencia de la cultura, en este caso de la cultura maya.

Las ideas expuestas en el discurso de Julio y Javier, si bien no presentan una contradicción importante con la imagen turística promovida, sí señalan particularidades o énfasis que están ausentes de esta, como la recuperación de los saberes locales y la búsqueda de fuentes alternas de información que no aparecen en la imagen turística. Consideramos que esta situación se debe fundamentalmente a la interpretación local de la imagen, amalgamada con el discurso de un profesional del turismo, y de una visión de este que debe nutrirse de ambas fuentes para distinguirse entre la oferta de alternativas de mediación turística, pero también de un contacto con la población local para activar conversaciones y concretar la imagen in situ.

Lo que hemos querido ofrecer en las páginas anteriores no es otra cosa que la apropiación de la imagen turística y su reconfiguración, mínima si se quiere y en el ámbito local, desde una perspectiva del turismo y sus impactos, de Izamal como pueblo mágico y de las tradiciones y convivencias con locales como fuentes alternativas en los discursos y prácticas de los guías turísticos de Izamal.

\section{Conclusiones}

Como hemos argumentado a lo largo de este artículo, la imagen turística de Izamal se nutre de las visiones, conocimientos y experiencias de diversos actores que en su conjunto construyen, reproducen y transmiten una imagen bastante homogénea de la ciudad.

Los folletos y las páginas de internet de promoción turística retoman ciertos elementos culturales de Izamal para moldear su imagen: el convento de san Antonio de Padua, las pirámides, el color amarillo y una concepción de Izamal como ciudad de las "tres culturas". Se trata de lo que Urry (1990) denomina una imagen romántica caracterizada por una belleza "natural" inalterada. Esta idea de imagen romántica es la que se encuentra detrás 
del PPM materializada en sus requerimientos para ingresar al programa, y sobre los cuales se construye la imagen turística de Izamal. Una imagen que ha sido construida, como se observa en la propuesta de la ciudad como pueblo mágico, que representa solamente a los sectores más privilegiados, y más recientemente se ha conjugado con el fomento de talleres artesanales desde una perspectiva asistencialista promovida desde la iniciativa privada.

Los guías de turistas locales son agentes activos y de gran importancia en la conformación de esta imagen, pues son ellos quienes se encuentran en contacto directo con los turistas. Puede señalarse que los guías transmiten una imagen turística "oficial" de la ciudad a través de discursos que son el resultado de la visión gubernamental. Esta visión está fuertemente relacionada con la pertenencia de la ciudad al PPM de la Sectur, pues es este organismo el que dicta las características que debe tener una localidad para poder ser considerada como pueblo mágico. Por ello, es interesante notar que los atractivos que reconocen los guías turísticos como parte de la oferta que presenta Izamal a sus visitantes son los mismos que establece el PPM. Estos atractivos son la arquitectura, los edificios emblemáticos, las fiestas y tradiciones, la producción artesanal y la cocina tradicional. El que todos estos elementos hayan sido mencionados por los guías muestra el proceso de construcción de una imagen turística que se nutre de diversas fuentes y que es reproducida constantemente para afirmar o reafirmar su legitimidad.

Los elementos culturales e históricos seleccionados están inscritos por igual en la idea de lo mágico como elemento integrador y cohesionador, de esta manera se crea un criterio, no siempre lo suficientemente explícito, de lo que es mágico y de lo que no es mágico de una población. Lo mágico, así, pasará a formar parte del discurso laboral de los guías turísticos.

Justamente por recibir de manera constante cursos de capacitación, los guías también reproducen una imagen "oficial" de la ciudad. Estos cursos de igual modo los legitiman como poseedores de un conocimiento "experto" sobre Izamal. Dos cosas, sin embargo, enriquecen la imagen turística de la ciudad: la primera de ellas tiene que ver con su visión personal de la localidad y al mismo tiempo con su propia interpretación de lo mágico, lo que consideran relevante y de mayor importancia para transmitir, tales como ciertas creencias locales, anécdotas y experiencias personales que se vinculan con la trama turística, pretendiendo dar una imagen que articule en un solo discurso la visión oficial y su "complemento" particular que proviene de las trayectorias personales. Lo anterior proviene de fuentes de información a las que usualmente no se recurre para construir la imagen. En este sentido, a los guías les parece fundamental recuperar los saberes locales, particularmente de las "personas antiguas", quienes nutren las narraciones alternativas y complementarias que a su vez proporcionan sabores y colores distintos a la imagen oficial. Un segundo elemento está relacionado directamente con la necesidad que ven los guías de que haya un impacto en la economía de los locales, como cuando señalan la importancia de que los recorridos propuestos se hagan a pie o en bicicleta, de tal manera que puedan acercarse a la población local y consumir diversos productos en tiendas de abarrotes y en la renta misma de las bicicletas, con lo cual se fortalecería una imagen que permitiera observar la vida de la ciudad con alma de pueblo, al relacionarse directamente con las personas que lo conforman; con ello se genera la idea de convivencia que creen necesario para sentir la localidad. Así, se amplía la noción de imagen turística, pues implica más relaciones y acercamientos con nuevos paisajes, nuevas rutas y nuevas conversaciones.

Se trata entonces, desde nuestro punto de vista, de un proceso de revaloración cultural que busca concretarse en referentes alternativos y dar un sello aún más personal y particular a la imagen turística de Izamal. En un plano más amplio, se trata de procurar los espacios para que otras voces, especialmente las locales, se incorporen a la imagen turística y con ello acerquen, no solamente a los turistas hacia narraciones y prácticas no consideradas en esta imagen, sino también a cambiar la propia percepción local de los turistas y su relación con ellos. 


\section{Notas}

${ }^{1}$ Revisar en particular los volúmenes III, IV y V, correspondientes a los años 2011, 2013 y 2015.

${ }^{2}$ La trascendencia de este programa es tal, que incluso Ecuador ha replicado el modelo para que en un futuro cercano tenga sus pueblos mágicos; para ello ha trabajado de manera cercana con la Secretaría de Turismo de México, y recientemente ha vislumbrado el potencial de más de diez localidades para convertirse en los primeros pueblos mágicos de Ecuador (Caivinagua, 2019).

${ }^{3}$ Al cuestionar a un policía turístico acerca de este nombramiento, comentó que Izamal fue la localidad que sirvió como modelo para la creación del Programa de Pueblos Mágicos. La Gaceta Parlamentaria del 27 de marzo de 2002, en la que se relata la sesión del 26 de marzo de 2002 de la Cámara de Diputados, señala que el ayuntamiento de Izamal elaboró en el año 2001 un proyecto turístico integral para el municipio, el cual fue presentado ante la Secretaría de Turismo del gobierno federal. Según esta minuta, dicha secretaría no solo aprobó un techo presupuestal para que se llevara a cabo el proyecto mencionado, sino que también "adoptó el proyecto turístico integral elaborado originalmente por el H. Ayuntamiento como modelo piloto para que se aplicara en otros 99 municipios turísticos del país que serán incluidos, al igual que Izamal, en el Programa de Pueblos Mágicos" (Gaceta Parlamentaria, 2002). De ahí quizás se extendió la idea de ser el modelo para los pueblos mágicos.

${ }^{4}$ Esta investigación se realizó en el marco del cuerpo académico "Estudios sobre prácticas y representaciones culturales" de la Facultad de Ciencias Antropológicas de la Universidad Autónoma de Yucatán, México. Se trata de una investigación cualitativa basada en una investigación de campo realizada en el primer semestre de 2016 y en el primer semestre de 2019. Los materiales recabados en 2016 se emplearon primariamente para la elaboración de una tesis de licenciatura en Antropología Social (Guevara, 2019), posteriormente se complementaron y actualizaron en 2019 para la elaboración de este artículo. Lo que aquí se presenta y analiza forma parte de una investigación más amplia que cubrió múl- tiples aspectos de las dinámicas de mercantilización de la cultura en Izamal (Guevara, 2019). Aquí nos enfocamos principalmente en uno de sus agentes, los guías turísticos de Izamal, excluyendo otros análisis como la relación entre la oferta turística y los talleres artesanales, o bien, la oferta gastronómica y el consumo turístico, que serán motivo de otros trabajos. En relación directa con este artículo empleamos las entrevistas semiestructuradas que realizamos a los dos únicos guías de turistas locales que cuentan con la debida certificación federal y que ofrecían sus servicios en el atrio del convento de Izamal. También entrevistamos a los cinco policías turísticos que proporcionaban información a los turistas de manera regular, sin involucrarse en tours, pero por razones de espacio no incluimos información relacionada con este grupo, que ya no ofrece sus servicios. No realizamos un trabajo con guías no locales, pues se alejaban de los propósitos de la investigación. En algunos casos se trata de guías extranjeros a los cuales difícilmente se tiene acceso, tanto por no residir en la península como por sus breves estancias en la localidad. Sostuvimos conversaciones informales con guías de turismo del estado de Yucatán, pero no incluimos esta información por ser redundante, y por no apegarse al sentido de local empleado por Salazar, es decir, "personas que tienen un sentido particular del lugar y un específico estilo de vida, un cierto ethos y una cosmovisión" (2005:629). No obstante, cabe mencionar que otro grupo local, el de los llamados caleseros (conductores de calesas), también ofrece servicios de tour, por lo que tangencialmente ofrecemos algunas de sus percepciones de Izamal y su turismo. Realizamos observaciones directas y participantes sobre el trabajo de los guías de turismo, al mismo tiempo que formamos parte de sus tours en alguna ocasión. Complementamos esta información con el análisis de sitios electrónicos y folletos turísticos, con el fin de caracterizar los imaginarios turísticos que se han desarrollado sobre Izamal en el contexto del desarrollo turístico del estado de Yucatán y de la península del mismo nombre. Cabe mencionar también que ambos autores somos yucatecos residentes en la ciudad de Mérida, y que en distintas ocasiones y por diversos motivos hemos actuado como guías en 
Izamal, atendiendo visitas de colegas de otras partes de México y del mundo, y al mismo tiempo hemos sido, en numerosas ocasiones, turistas de la localidad. Además, uno de los autores realizó, hace ya algunas décadas, un trabajo de fotografía etnográfica para las fiestas patronales del Cristo de Sitilpech y de la virgen de Izamal. Por lo anteriormente expuesto, ha habido un contacto recurrente con la población, tanto en términos informales como profesionales.

${ }^{5}$ Esta idea ha sido ampliada por Maoz (2006), quien propone la idea de mirada dual para señalar el papel activo que tienen los anfitriones, construyendo ellos mismos su propia mirada de los turistas. También ha sido cuestionada por autores como MacCannell (2001) y por Bruner (2005), cuando se preguntan sobre la ausencia de agencia en la construcción de la mirada turística, inquisidora/cuestionadora. Bruner propone la idea de questioning gaze como referente de esta situación.

${ }^{6}$ El interés académico por Izamal ha sido una constante, dada su continuidad e importancia como asentamiento prehispánico, colonial y contemporáneo. Sin la intención de ser exhaustivos, este interés se manifiesta en trabajos arqueológicos (Burgos, Estrada y García, 2003; Burgos y Millet, 2006; Burgos, Palomo y Kantún, 2013; Quiñones Cetina, 2006), así como de su arquitectura colonial (Ancona, 1993; Millet y Burgos, 1993). La importancia religiosa de Izamal, y en especial de su imagen, también ha sido motivo de análisis (Fernández y Negroe, 2006; Pascacio, 2013 y 2015). Con la inclusión de Izamal en el PPM, se han producido distintos trabajos que dan cuenta de su situación en años recientes (Alvarado-Sizzo, 2016; Alvarado-Sizzo, Propin y Sánchez, 2017; Bolio y Lara, 2018) y también de sus perspectivas turísticas a futuro en el marco del proyecto Tren Maya, que tendría una estación en la ciudad (Viana, Santos y Pereyra, 2019).

${ }^{7}$ En 1995 se instaló en Izamal la manufacturera Lee de México S.A. de C.V., empresa internacional dedicada al ramo textil y que hasta estos días permanece en funcionamiento.

${ }^{8}$ Entre las acciones que develan este compromiso se encuentran las siguientes: a mediados de la década de los noventa se impulsa un parador turístico y se ofrece un servicio de visitas mediante la habilitación de un tren turístico (Mérida-Izamal); en 2001 se propone y se obtiene el ingreso de Izamal al programa turístico Pueblos Mágicos; en 2008 se incluye Izamal en la lista tentativa de la UNESCO con la intención de proponer en un futuro su nominación como patrimonio de la humanidad (Alvarado-Sizzo, 2016); en 2016 es sede del Congreso Internacional de Mayistas, y de acuerdo con el proyecto Tren Maya del gobierno federal, Izamal será una de las estaciones de este servicio.

${ }^{9}$ La incorporación de una localidad al programa se hace por medio de la conformación de un comité que funcione como interlocutor entre los niveles de gobierno y la población de la localidad y que también solicite dicha incorporación a la Secretaría de Turismo Federal. En el caso de Izamal, este comité estuvo conformado en 2002 por el gobernador del estado (Patricio Patrón Laviada, 2001-2007), la secretaria de Turismo (Carolina Cárdenas Sosa), el presidente municipal de Izamal (William Renán Sosa Altamira), dos organismos del ayuntamiento de Izamal (la Dirección de Turismo Municipal y la Dirección de Obras Públicas) y por organizaciones del sector privado y social (hotel Green River, hacienda Katanchel, restaurante Kinich Kakmó, restaurante Tumbel Lol, Asociación Mexicana de Hoteles, Asociación de Agentes de Promotores de Turismo de Yucatán y la Universidad Autónoma de Yucatán) (Chan, 2014). Las actividades que priorizó este comité desde el nombramiento de la ciudad fueron las relacionadas con el mejoramiento de la infraestructura, como la remodelación de fachadas, el cableado subterráneo, la pavimentación de las calles del centro histórico y la siembra de árboles en los espacios públicos.

10 "[...] un turista es mitad peregrino y un peregrino es mitad turista" (Turner y Turner, 1978:20).

${ }^{11}$ Los pobladores del lugar ofrecen distintas explicaciones del porqué se decidió pintar toda la ciudad de este característico color: la primera de ellas se sirve de la historia prehispánica del lugar, pues se dice que la ciudad es amarilla porque amarillo es el color del maíz, y según el Popol-Vuh el hombre fue formado con maíz; una segunda versión señala que la ciudad se pintó de color amarillo en honor a Juan Pablo II y a la visita que realizó 
a Izamal en 1993; el color amarillo de la ciudad imitaría, pues, los colores del Vaticano. Una tercera versión, con un sentido más práctico que las anteriores, explica que la pintura amarilla combinada con cal aleja a los insectos. Primero se pintaron algunas casas por esta razón, y posteriormente el patrón continuó en el resto de la ciudad. Algunas tiendas de pintura en la ciudad de Mérida venden el color que han denominado "amarillo Izamal".

${ }^{12}$ Disponible en https://datatur.sectur.gob.mx/SitePages/ ActividadHotelera.aspx. Quizás esta estadística cambiaría si se considerara a los turistas religiosos que pernoctan en las casas de los organizadores de las fiestas religiosas de la localidad, particularmente de los gremios, y que quedan fuera de la información oficial.

${ }^{13}$ Vale la pena enfatizar que la promoción de esta imagen de la ciudad no deja de estar exenta de intereses particulares por parte de quienes financian el desarrollo desde su particular visión. Así, Fomento Cultural Banamex promovió la apertura de ocho talleres artesanales, a los que reconoció a través de su programa Grandes Maestros del Arte Popular, financiándolos con equipamiento e infraestructura. Asimismo, abrió un Centro Cultural y Artesanal para poner en valor no solamente el arte popular local y regional, sino también de otras partes de México, pues crearon una exhibición que se expone en un pequeño museo que forma parte del recinto. Fomento Cultural Banamex tiene por lo menos dos museos más en operación: uno en Mérida, Yucatán, denominado Casa de Cultura Banamex Museo Casa Montejo, y otro en Ciudad de México, llamado Museo Palacio Cultural Banamex (antiguo Palacio de Iturbide).

${ }^{14}$ En el Tianguis Turístico 2018, realizado en Mazatlán, Sinaloa, el recorrido nocturno (videomapping) Senderos de Luz ganó el reconocimiento a la diversificación del producto turístico mexicano 2018. Ver http://www. eluniversal.com.mx/destinos/yucatan-recibe-reconocimiento-por-paseo-nocturno (consultado el 24 de abril de 2018).

${ }^{15}$ La publicidad de los atractivos turísticos de la región emplea también recursos de diseño gráfico para dar cuenta de la relación entre estos atractivos y la localidad con la finalidad de fortalecer la "localización" de estos.
En este sentido, emplean colores y tipografía fuertemente vinculada con caracteres mayas (Rogal, 2012).

${ }^{16}$ https://www.mexicodestinos.com/blog/2014/10/5-imprescindibles-para-disfrutar-de-izamal-pueblo-magico/

${ }^{17}$ La Secretaría de Turismo federal certifica a los guías turísticos a través de la Dirección General de Certificación Turística, de acuerdo con las Normas Mexicanas Oficiales NOM-08-TUR-2002 y NOM-09-TUR-2002. Ver https:/www.gob.mx/sectur/acciones-y-programas/acreditacion-de-guias-de-turistas (consultado el 12 de octubre de 2018).

${ }^{18}$ Además de los guías de turismo y de los ahora desaparecidos policías turísticos, son los caleseros (conductores de calesas, nombre que en Yucatán se da a los coches de caballo para pasajeros) quienes tienen una relación importante con los visitantes. Los caleseros son de la ciudad o de sus cercanías, y ofrecen tours a los visitantes en el parque Zamná. Todos los días se pueden encontrar en la Calle Veinte, donde estacionan sus calesas, frente al costado norte del convento. Para hacer más atractivos sus servicios, decoran las cabezas de sus caballos con coloridos sombreros de jipi, para darles un toque de color y hacerlos más pintorescos. Los recorridos que ofrecen por la ciudad son variados, pero todos ellos atienden a los sitios arqueológicos de la ciudad, además de los parques y capillas más destacados. La principal diferencia con los guías de turismo es que no cuentan con certificación oficial, y por tanto no tienen una educación formal y profesional relacionada con lo que se refiere a los servicios turísticos ni se actualizan permanente sobre las recientes investigaciones arqueológicas e históricas. Tampoco cuentan con los contactos académicos necesarios para ampliar sus conocimientos sobre estas materias y reducen sus explicaciones a motivos generales de los sitios visitados; no por ello dejan de ser entretenidos y certeros. Tienen una visión muy enfocada hacia su trabajo como conductores de calesa y a la inversión diaria que requiere mantener un caballo en buenas condiciones.

${ }^{19}$ Esta idea coincide con los registros que proporcionan Alvarado-Sizzo, Propin y Sánchez (2017) en relación con el lugar de procedencia de los turistas internacionales que visitan Izamal, por lo menos durante la fiesta patronal en diciembre. 
${ }^{20}$ Este programa señala que un pueblo mágico es aquel que: "a través del tiempo y ante la modernidad, ha conservado, valorado y defendido, su herencia histórica, cultural y natural; y la manifiesta en diversas expresiones a través de su patrimonio tangible e intangible" (Sectur, 2014).

${ }^{21}$ La idea de que la población maya es uno de los principales atractivos se reafirma en los talleres artesanales promovidos por Fomento Cultural Banamex. En nuestra visita a uno de ellos en abril de 2019, el artesano nos recibió con un discurso de bienvenida en lengua maya, que luego nos tradujo, para después ir articulando de manera intermitente oraciones en la misma lengua para mostrar sus habilidades y productos artesanales.

22 "Morral. Bolsa tejida de henequén o pita a propósito para cargarla terciada y llevar en ella comestibles o bastimento en general" (Güémez, 2011:295).

23 "Del maya xanab, zapato y k'éewel, cuero, piel. Alpargata indígena de suela de cuero" (Güémez, 2011:347).

${ }^{24}$ Jipi, apócope de jipijapa. Sombrero de jipijapa. "Prenda masculina y aun femenina, de ala ancha, que se considera tanto más fina, manuable y plegadiza, entre mayor número de hilos de palma sirvieron para su manufactura" (Güémez, 2011:305).

${ }^{25}$ Al no hablar de "pirámide" y sí de "basamento", Javier puede estar demostrando el conocimiento que obtuvo en su capacitación como guía turístico. El lenguaje técnico de la arqueología inscribe su discurso en la academia y legitima su discurso (Rogal, 2012; Salazar, 2006)

${ }^{26}$ Sinónimo de mukbipollo: "Torta grande de maíz amasada con abundante manteca” (Güémez, 2011:240).

${ }^{27}$ Las prácticas de este tipo han sido denominadas neochamánicas. Consisten en la recreación de ciertos rituales mayas prehispánicos que buscan el bienestar de las personas por medio de limpias, o bien se realizan matrimonios según la tradición maya. Por realizarse fuera de contexto (espacial y temporal) se trata de tradiciones inventadas en los términos de Bendix (1989).

${ }^{28}$ Se está refiriendo a los nombres de cuatro restaurantes de la ciudad.

\section{Referencias}

Adams, Kathleen M. (1997). "Ethnic Tourism and the Renegotiation of Tradition in Tana Toraja (Sulawesi, Indonesia)". En Ethnology, 36(4), 309-320.

Adams, Kathleen M. (2004). "The Genesis of Touristic Imagery Politics and Poetics in the Creation of a Remote Indonesian Island Destination". En Tourist Studies, 4(2), 115-135.

Adler, Judith (1989). “Origins of Sightseeing”. En Annals of Tourism Research, 16, 7-29.

Alvarado-Sizzo, Ilia (2016). "Territorial Dynamics of Cultural Tourism in Izamal, Yucatan, Mexico". En GeoJournal, 80(3), 751-770.

Alvarado-Sizzo, Ilia, Enrique Propin Frejomil y Álvaro Sánchez Crispín (2017). "Religious Tourism in Souther Mexico: Regional Scopes of the Festival of the Immaculate Conception". En Geoforum, 83, 14-25.

Álvarez de la Torre, Jaime y Diego Rodríguez-Toubes Muñiz (2013). “Riesgo y percepción en el desarrollo de la imagen turística de Brasil ante los mega-eventos deportivos". En Pasos. Revista de Turismo y Patrimonio Cultural, 11(3), 147-154.

Ancona Mena, Raúl (1993). "Izamal, Yucatán: su evolución urbano arquitectónica”. En Cuadernos de Arquitectura Virreinal, 14, 15-30.

Arnold, Channing y Frederick J. Tabor Frost ([1909]2014). The American Egypt: A Record of Travel in Yucatan. Londres: Hutchison \& Co.

Baños Ramírez, Othón (2010). "The Decline and Collapse of Yucatán's Henequen Agro-Industry: Neoliberalism Reconsidered". En Edward D. Terry, Ben W. Fallaw, Gilbert M. Joseph y Edward H. Moseley (eds.), Peripheral Visions. Politics, Society and the Challenges of Modernity in Yucatán. Tuscaloosa: The University of Alabama Press, pp. 144-169.

Baudrillard, Jean (1977). Cultura y simulacro. Barcelona: Kairós.

Bellota, Luis Ángel (2017). Programa de Pueblos Mágicos: valorización turística de la cultura. México: Centro de Estudios Sociales y de Opinión Pública.

Benavides, O. Hugo (2013). "Working/Touring the Past: Latin American Identity and the Political Frustration 
of Heritage". En International Journal of Historical Archaeology, 17, 245-260.

Bendix, Regina (1989). "Tourism and Cultural Displays: Inventing Traditions for Whom?”. En Journal of American Folklore, 102, 127-146.

Bolio Rosado, María Isabel e Ileana Beatriz Lara Navarrete (2018). "Pueblos mágicos y sus impactos. El caso de Izamal". En García Gómez, Carmen, María Isabel Bolio Rosado y Margarita de Abril Navarro Favela (coords.), Turismo y sus impactos. Sociales, económicos y ambientales. México: Universidad Intercultural de Quintana Roo, Red de Estudios Multidisciplinarios de Turismo, Secretaría de Fomento Turístico de Yucatán, pp. 49-95.

Bourdieu, Pierre (1973). "Campo intelectual y proyecto creador". En Jean Pouillon, Marc Barbut, A. J. Greimas, Maurice Godelier, Pierre Bourdieu y Pierre Macherey, Problemas del estructuralismo. México: Siglo XXI , pp. 135-182.

Bruner, Edward M. (2005). Culture on Tour: Ethnographies of Travel. Chicago y Londres: The University of Chicago Press.

Burgos Villanueva, Rafael y Luis Millet Cámara (2006.) "Izamal: una aproximación a su arquitectura". En Alfredo Barrera y Ruth Gubler (eds.), Los mayas de ayer y hoy. Mérida: Instituto Nacional de Antropología e Historia, Patronato CULTUR, Universidad Autónoma de Yucatán, t. I, pp. 132-155.

Burgos Villanueva, Rafael, José Estrada Faisal y José García (2003). "Una aproximación al patrón de asentamiento del sitio de Izamal, Yucatán”. En Los Investigadores de la Cultura Maya 1l. Campeche: Universidad Autónoma de Campeche, vol. II, pp. 312-324.

Burgos Villanueva, Rafael, Yoly Palomo Carrillo y Guillermo Kantún Cabrera (2013). "La estructura Kabul, Izamal, Yuc: irepresentación de un personaje mítico o histórico?" En Los investigadores de la Cultura Maya 21. Campeche: Universidad Autónoma de Campeche. Tomo 1, pp. 200-224.

Cahyadi, Hery Sigit (2016). "Authenticity and Commodification of Culture at Puri Anyar Kerambitan as Royal Tourism Attraction in Tabanan Regency, Bali Province, Indonesia”. En Journal of Social Science Studies, 3(1), 1-11.
Calonge Reíllo, Fernando (2011). "Otras formas de turismo patrimonial. El caso de las ex haciendas de Xalapa". En Andamios, 8(16), 261-286.

Caivinagua, Xavier (2018). "Ecuador podría tener sus propios 'Pueblos Mágicos' gracias a México”. En RT, 6 de agosto. Disponible en https://actualidad.rt.com/ actualidad/284108-mexico-ayudara-ecuador-pueblos-magicos (consultado el 18 de abril de 2019).

Camprubí, Raquel, Jaume Guia y Jordi Comas (2009). "La formación de la imagen turística inducida: un modelo conceptual". En Pasos. Revista de Turismo y Patrimonio Cultural, 7(2), 255-270.

Canto Sáenz, Rodolfo (2001). Del henequén a las maquiladoras. La política industrial en Yucatán 1984-2001. México: Instituto Nacional de Administración Pública, Universidad Autónoma de Yucatán.

Castilla Ramos, Beatriz (2004). Mujeres mayas en la robótica y líderes de la comunidad. Tejiendo la modernidad. Mérida: Universidad Autónoma de Yucatán.

Chan May, Lissie Yamil (2014) "Marketing de ciudad y beneficio social. El caso de la marca 'Izamal, pueblo mágico"'. Trabajo terminal de licenciatura en Diseño del Hábitat, Universidad Autónoma de Yucatán, Mérida, Yucatán.

Cobb, Russell (ed.) (2014). The Paradox of Authenticity in a Globalized World. Nueva York: Palgrave Macmillan.

Cohen, Eric (1988). "Authenticity and Commoditization in Tourism". En Annals of Tourism Research, 15, 371-386.

Cohen, Eric (2005). "Principales tendencias en el turismo contemporáneo”. En Política y Sociedad, 42(1), 11-24.

Córdoba y Ordoñez, Juan (2009). "Turismo, desarrollo y disneyzación: ¿Una cuestión de recursos o de ingenio?". En Investigaciones Geográficas. Boletín del Instituto de Geografía, 70, 33-54.

Depetris, Carolina (ed.) (2015). Viajeros por el mundo maya. México: Universidad Nacional Autónoma de México.

Donaire, José A. y Núria Galí (2011). “La imagen turística de Barcelona en la comunidad de flickr". En Cuadernos de Turismo, 27, 291-303.

Du Cros, Hilary y Bob McKercher (2012). Cultural Tourism: The Partnership between Tourism and Cultural Heritage Management. Londres: Routledge. 
Estrella Pozo, Juan Antonio (2015). "Izamal, Yucatán. ¿Tradición o invención?” En Liliana López Levi, Carmen Valverde Valverde y María Elena Figueroa Díaz (coords.). Pueblos mágicos. Una visión interdisciplinaria. México: Universidad Autónoma Metropolitana, Universidad Nacional Autónoma de México, vol. II, pp. 45-61.

Fabian, Johannes (2002). Time and the Other: How Anthropology Makes its Object. Nueva York: Columbia University Press.

Fernández Repetto, Francisco y Genny Negroe Sierra (1997). "Los cleros en dos santuarios marianos de Yucatán”. En Germán Ferro Medina (comp.), Religión y etnicidad en América Latina. Bogotá: Instituto Colombiano de Antropología, t. 1, pp. 171-178.

Fernández Repetto, Francisco y Genny Negroe Sierra (2006). Izamal festivo. Mérida: Universidad Autónoma de Yucatán, Instituto de Cultura de Yucatán, CONACYT

Fernández Repetto, Francisco (2015). "Nostalgia and Tourism: Narratives of Yucatán's Tangible Heritage”. En Culture $\sim$ History Digital Journal, 4(2).

Gaceta Parlamentaria (2002). "Con punto de acuerdo para que la Comisión de Turismo de la Cámara de Diputados, investigue la situación del Programa de los Pueblos Mágicos, en el municipio de Izamal, en el estado de Yucatán, presentada por la diputada Rosa Elena Baduy Isaac, del grupo parlamentario del PRI, en la sesión del martes 26 de marzo de 2002". En Gaceta Parlamentia, V(968), 27 de marzo. Disponible en http:/gaceta. diputados.gob.mx/Gaceta/58/2002/mar/20020327. html (consultado el 8 de enero de 2019).

Galí Espelt, Núria (2005). "La humanización de las imágenes emitidas por la publicidad de los destinos turísticos monumentales: el caso de Girona”. En Pasos. Revista de Turismo y Patrimonio Cultural, 3(2), 273-281.

Gallarza, Martina, Irene Gil Saura y Haydeé Calderón García (2002). "Destination image: Towards a Conceptual Framework". En Annals of Tourism Research, 29(1), 56-78.

Gibson, Jamesha (2015). "[Preservation Glossary] Today's Word: Heritage Tourism”. En National Trust for Historic Preservation, 17 de junio. Disponible en https://savingplaces.org/stories/preservation-glossary-todays-word-heritage-tourism \#.YAXM9egzbIV (consultado el 21 de julio de 2020).

Gotham, Kevin Fox (2007). "Destination New Orleans: Commodification, rationalization, and the rise of urban tourism”. En Journal of Consumer Culture 7(3), 305-334

Greenwood, Davydd J. (1989). "Culture by the Pound: An Anthropological Perspective on Tourism as Cultural Commoditization". En Valene L. Smith (ed.). Hosts and Guests: The Anthropology of Tourism. Filadelfia: University of Pennsylvania Press, pp. 171-185.

Güémez Pineda, Miguel (2011). Diccionario del español yucateco. México: Universidad Autónoma de Yucatán, Plaza y Valdés Editores.

Guevara Rosado, Mariana (2019). Tradiciones en venta. Turismo y mercantilización de la cultura en Izamal, Yucatán. Tesis de licenciatura en Antropología Social, Universidad Autónoma de Yucatán.

Hernández Mar, Raúl (coord.) (2015). Pueblos Mágicos: discursos y realidades. Una mirada desde la política pública y la gobernanza. México: Juan Pablos Editor, Universidad Autónoma Metropolitana-Unidad Lerma.

Hervik, Peter (1999). "The Mysterious Maya of National Geographic”. En Journal of Latin American Anthropology, 4(1), 166-197.

Himpele, Jeff y Quetzil Castañeda (dir.) (1997). Incidents of Travel in Chichen Itza [documental:]. Watertown, MA: Documentary Educational Resources.

Iwashita, Chieko (2006). "Media Representation of the UK as a Destination for Japanese Tourist". En Tourist Studies, 6(1), 59-77.

Lee, Suman, María Lulu Rodríguez y Sela Sar (2012). "The Influence of Logo Design on Country Image and Willingness to Visit: A Study of Country Logos for Tourism". En Public Relations Review, 38(4), 584-59l.

Lizana, Bernardo ([1893]1995). Devocionario de Nuestra Señora de Izamal y conquista espiritual de Yucatán. México: Universidad Nacional Autónoma de México.

López Levi, Liliana y Carmen Valverde Valverde (coords.) (2016). Los imaginarios del turismo. El caso de los pueblos mágicos. México: Universidad Autónoma Metropolitana, Universidad Nacional Autónoma de México. 
López Levi, Liliana, Carmen Valverde Valverde, Anna María Fernández Poncela y María Elena Figueroa Díaz (coords.) (2015). Pueblos mágicos. Una visión interdisciplinaria. México: Universidad Autónoma Metropolitana-Unidad Xochimilco, Universidad Nacional Autónoma de México.

López Santillán, Ángeles A. y Gustavo Marín Guardado (2010). "Turismo, capitalismo y producción de lo exótico: Una perspectiva crítica para el estudio de la mercantilización del espacio y la cultura". En Relaciones, XXI(123), 219-258.

MacCannell, Dean ([1976]1999). The Tourist: A New Theory of the Leisure Class. Los Angeles: University of California Press.

MacCannell, Dean (2001). "Tourist agency". En Tourist Studies. 1(1), 23-37.

Maoz, Darya (2006). "The Mutual Gaze". En Annals of Tourism Research, 33(1), 221-239.

Millet Cámara, Luis y Rafael Burgos Villanueva (1993). "La guardianía de Izamal y sus construcciones religiosas en el siglo XVI". En Cuadernos de Arquitectura Virreinal, 14, 3-14.

Morgan, Nigel y Annette Pritchard (2005). "On Souvenirs and Metonymy: Narratives of Memory, Metaphor and Materiality". En Tourist Studies, 5(29), 29-53.

Nicoletta, Raffaella y Rocco Servidio (2012). “Tourists' Opinions and Their Selection of Tourism Destination Images: An Affective and Motivational Evaluation". En Tourism Management Perspectives, 4(1), 19-27.

Notimex (2019). "Tianguis de Pueblos Mágicos en Pachuca; hay que ir". En Excelsior, 3 de octubre. Disponible en https://www.excelsior.com.mx/nacional/ tianguis-de-pueblos-magicos-en-pachuca-hay-queir/1339872 (consultado el 23 de octubre de 2019).

Pascacio Guillén, Bertha (2013). "Entre el mito, la imagen, el alma y el ánima. Una visión interdisciplinaria de la virgen de Izamal, Yucatán”. En Estudios de la Imagen, 5(1), 64-73.

Pascacio Guillén, Bertha (2015). "Tras las huellas de una tradición: la Virgen de Izamal en Yucatán. Historia, cambios, permanencias y adaptaciones de una imagen de devoción". En EntreDiversidades, $1(4), 117-145$
Pérez Castro, Ana Bella, Julián Dzul Nah y Abraham Collí Tun (2019). "Izamal y la comercialización de lo mágico". En Ricardo Pérez Montfort y Ana Paula de Teresa (coords.), Cultura en venta. La razón cultural en el capitalismo contemporáneo. México: Debate, pp. 441-487.

Quiñones Cetina Lucía (2006). "Del preclásico medio al clásico temprano: Una propuesta de fechamiento para el área nuclear de Izamal, Yucatán". En Estudios de Cultura Maya, 28, 5l-65.

Rogal, Maria (2012). "Identity and Representation: The (Yucatec) Maya in the Visual Culture of Tourism". En Latin American and Caribbean Ethnic Studies, 7(1), 49-69.

Salazar, Noel B. (2005). "Tourism and Glocalization 'Local' Tour Guiding”. En Annals of Tourism Research, 32(3), 628-646.

Salazar, Noel B. (2006). "Touristifying Tanzania. Local Guide, Global Discourse". En Annals of Tourism Research, 33(3), 833-852.

Salazar, Noel B. (2012). "Tourism Imagineries: A Conceptual Approach”. En Annals of Tourism Research, 39(2), 863-882.

Santillán, Vilma Leonora (2010). "La fotografía como creadora de la imagen de un destino turístico. Buenos Aires a través de sus tarjetas postales". En Pasos. Revista de Turismo y Patrimonio Cultural, 8(1), 71-82.

Sectur (Secretaría de Turismo) (2014). "Guía de incorporación y permanencia. Pueblos Mágicos”. Disponible en http://www.sectur.gob.mx/wp-content/ uploads/2014/10/GUIA-FINAL.pdf (consultado el 27 de abril de 2018).

Sectur (Secretaría de Turismo) (2019). "Guía para la permanencia en el Programa Pueblos Mágicos 2019”. Disponible en http:/www.sectur.gob.mx/wp-content/uploads/2014/10/guiadepermanancia2019final. pdf (consultado el 30 de mayo de 2020).

Shepherd, Robert (2002). "Commodification, Culture and Tourism". En Tourist Studies, 2(2), 183-201.

Smith, Valene L. (1989). "Introduction". En Valene L. Smith (ed.). Hosts and Guests: The Anthropology of Tourism. Filadelfia: University of Pennsylvania Press, pp. 1-17.

Stephens, John L. ([1843]1963). Incidents of Travel in Yucatán. Nueva York: Dover Publications INC. 
Turner, Victor y Edith L.B. Turner (1978). Image and Pilgrimage in Christian Culture. Nueva York: Columbia University Press.

Tzuc Dzib, María Beatriz (2018). Aproximación al turismo religioso dentro de la fiesta patronal en Izamal, Yucatán. Tesina de maestría en Antropología Social. México: Universidad Autónoma Metropolitana-Unidad Iztapalapa.

Urry, John (1990). The Tourist Gaze. Leisure and Travel in Contemporary Societies. Londres: Sage.

Urry, John y Jonas Larsen (2011). The Tourist Gaze 3.0. Londres: Sage.

Vera Lima, Miguel F. (2018) "Izamal, ciudad de las tres culturas. Siglo XX”. En Karla Berrón Cámara y Mario Humberto Ruz (eds.), Izamal en el tiempo, una mirada religiosa, arqueológica y cultural. Mérida: Secretaría de Investigación, Innovación y Educación Superior del Gobierno del Estado de Yucatán.

Viana Cano, Julissa Janet, Raúl Alberto Santos Valencia y Andrés M. Pereyra Chan (2019). "La influencia del desarrollo regional en el turismo local”. En Enrique Pérez Campuzano, José Francisco Sarmiento Franco y Enrique Mota Flores (eds.), Impactos ambientales, gestión de recursos naturales y turismo en el desarrollo regional. México: Universidad Nacional Autónoma de México, Asociación Mexicana de Ciencias para el Desarrollo Regional, vol. II, pp. 555-571.

Yüksel, Atila y Olcay Akgül (2012). "Postcards as Affective Image Makers: An Idle Agent in Destination Marketing". En Tourism Management, 28(3), 714-725.

Imagen 1. Muestra de folletos de la promoción turística de Izamal

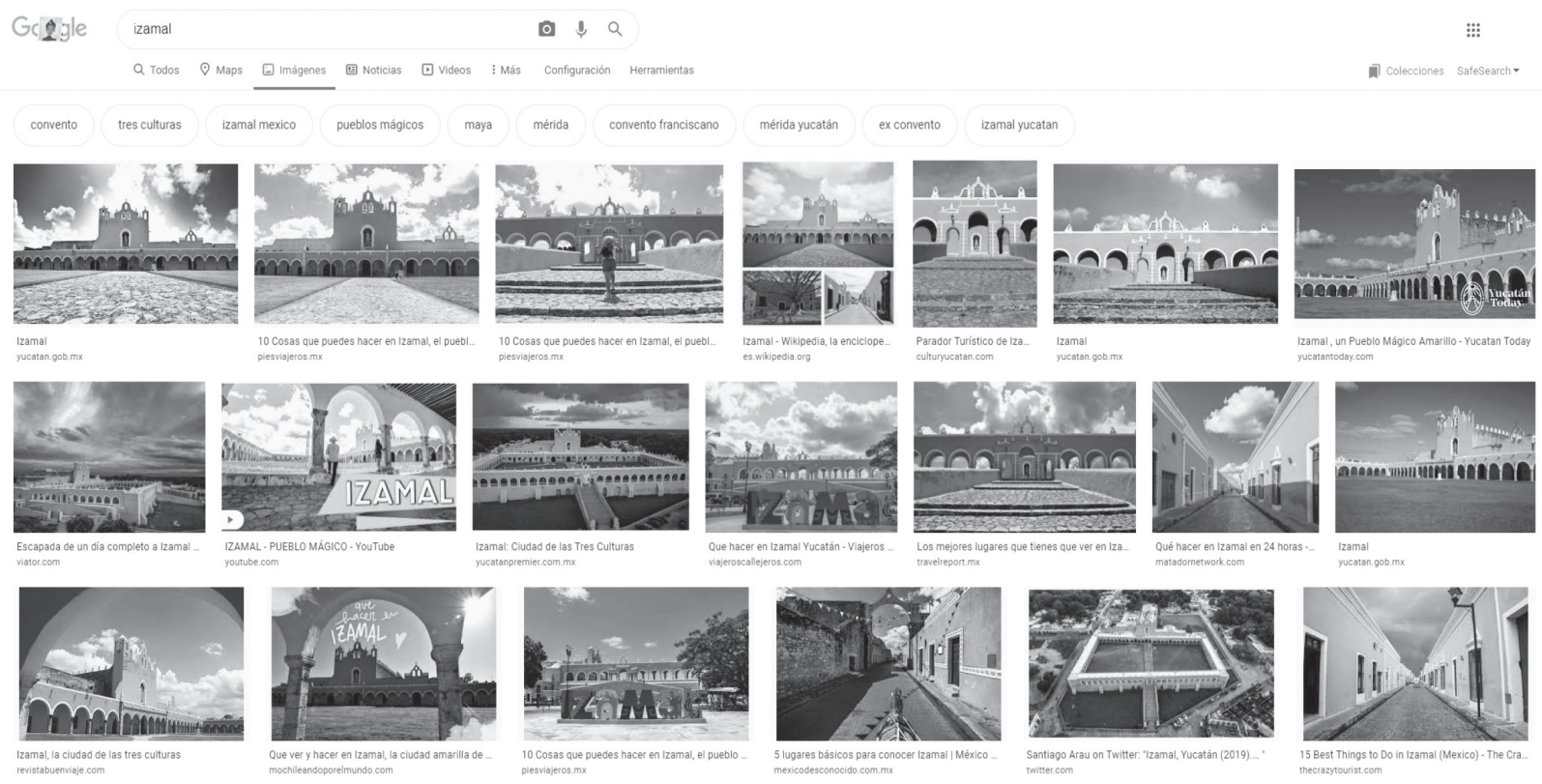

Fuente: de izquierda a derecha, corresponden a los gobiernos estatales de los períodos 2001-2007, 2007-2012 y 2012-2018. El primero y el último fueron realizados con la colaboración de Fomento Cultural Banamex. Ninguno de ellos reconoce la participación de algún agente (individual o colectivo) de la localidad. 
Imágenes 2 y 3 . Anverso de folleto y portada del libro en el que viene inserto
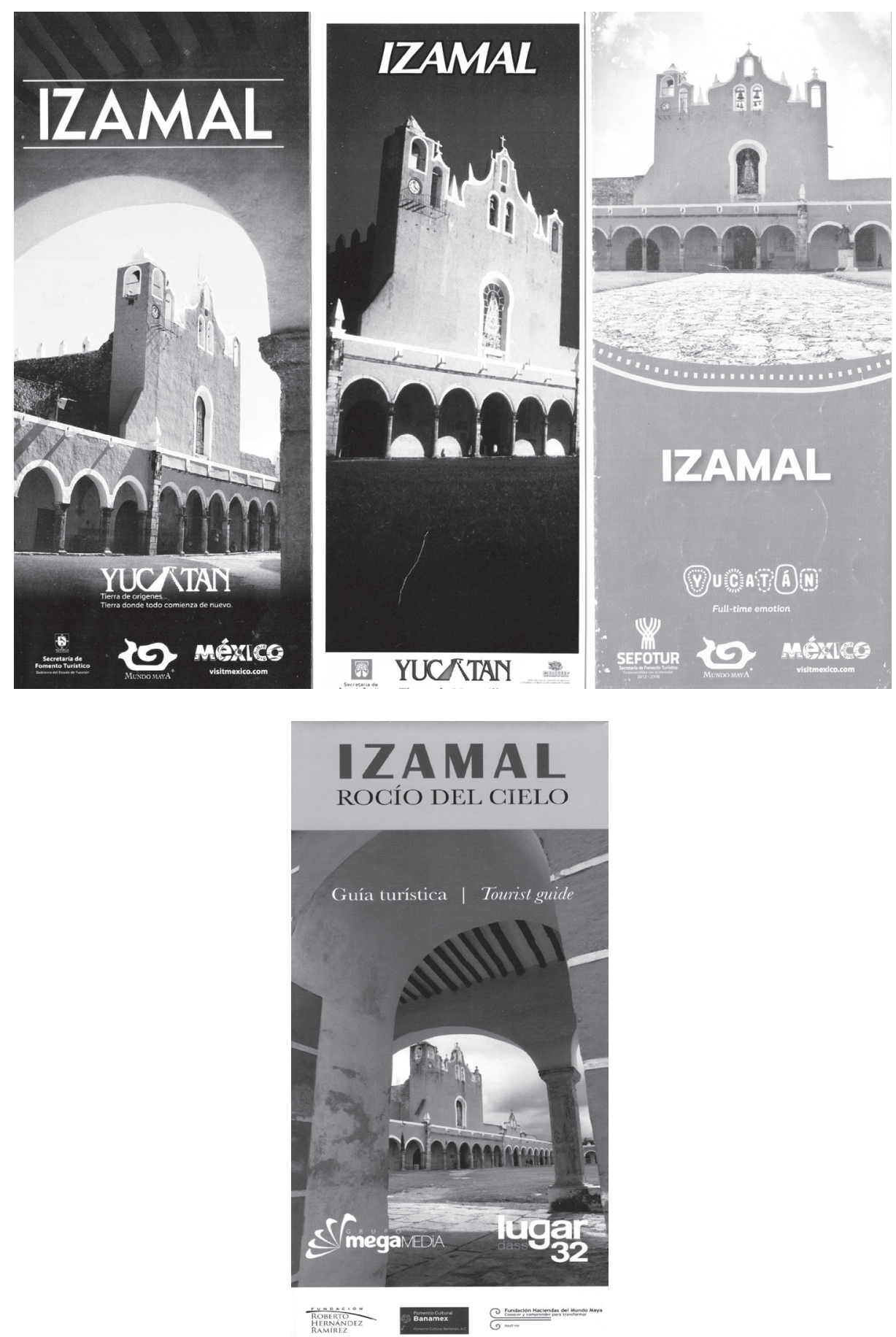

Fuente: Izamal, rocío del cielo. Guía turística. Mérida, Yucatán: Fundación Roberto Hernández Ramírez, Fomento Cultural Banamex, Fundación Haciendas del Mundo Maya. 
Imágenes 4 y 5. Anverso y reverso de la tarjeta de presentación de Julio Briceño
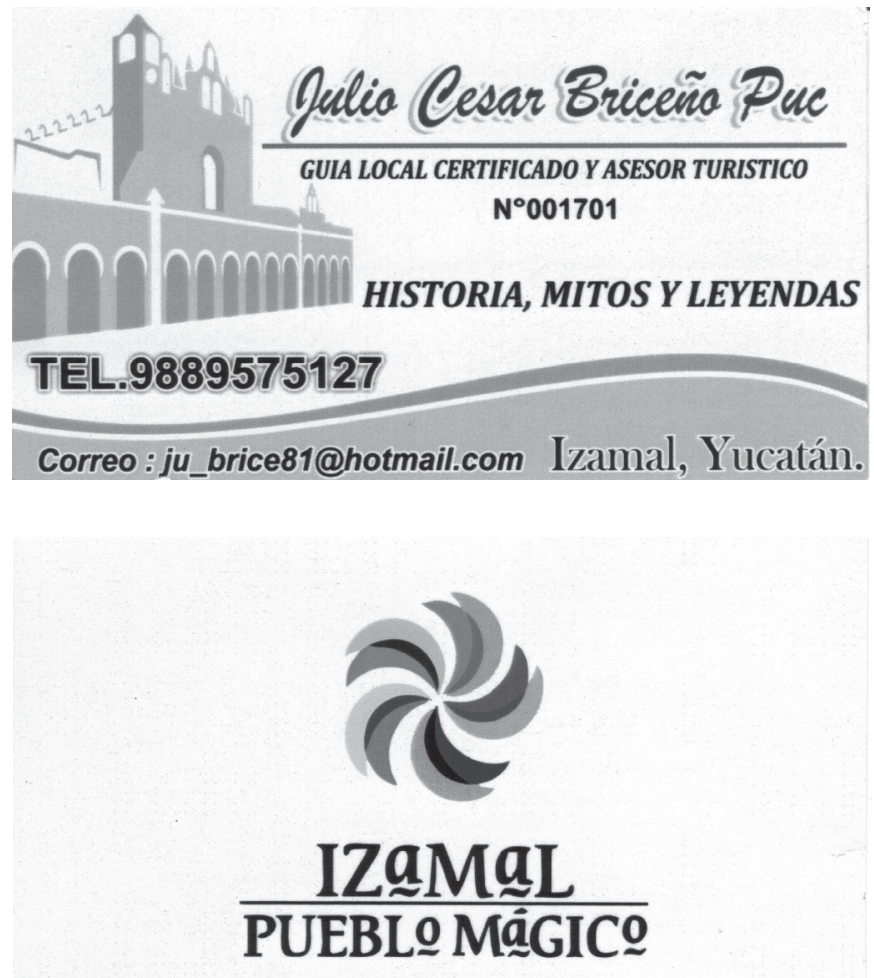

Fuente: Julio Briceño. Nótese el énfasis en la idea de mitos y leyendas y, por supuesto, el convento como el referente central de Izamal. En el reverso se confirma la idea de Izamal como parte del PPM, ocupando todo el espacio de la tarjeta y el logo del programa. 